\title{
Food value chain development in central New York: CNY Bounty
}

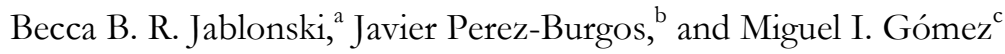

Submitted 18 February 2011 / Accepted 6 May 2011 / Published online 4 August 2011

Citation: Jablonski, B. B. R., Perez-Burgos, J., \& Gómez, M. I. (2011). Food value chain development in central New York: CNY Bounty. Journal of Agriculture, Food Systems, and Community Development, 1(4), 129-141. http://dx.doi.org/10.5304/jafscd.2011.014.015

Copyright (C) 2011 by New Leaf Associates, Inc.

\begin{abstract}
In the past 10 years, demand for locally grown food has increased dramatically. Concomitantly, small, commercial farms have declined disproportionately to small and large farms. The decline may be due to the lack of appropriately scaled marketing and distribution resulting from changing markets. This article presents a case study of a compo-

a Corresponding author: Becca B. R. Jablonski, PhD student, Department of City and Regional Planning, Cornell University, 314 West Sibley, Cornell University, Ithaca, NY 14853 USA; rebeccajablonski@,cornell.edu

b PhD student, Department of City and Regional Planning, Cornell University, 314 West Sibley, Cornell University, Ithaca, NY14853 USA; jip33@,cornell.edu

c Assistant Professor, Charles H. Dyson School of Applied Economics and Management, Cornell University, 246 Warren Hall, Cornell University, Ithaca, NY 14853 USA; mig7@,cornell.edu
\end{abstract}

Disclosure and acknowledgement: Becca Jablonski has served on the CNY Bounty executive advisory committee since 2008 and is now chair of its board of directors. She gratefully acknowledges the support of CNY Bounty founders J. Rebecca Hargrave and Phil Metzger, and CNY Bounty Project Coordinator Steven Holzbaur. nent of a food value chain started in 2007, Central New York (CNY) Bounty. CNY Bounty markets and distributes products produced by 119 small, commercial farms and processors to individual households, restaurants, natural food stores, and universities. In the past four years, CNY Bounty has experienced mixed success in terms of its economic viability, which can offer some important lessons for practitioners and contributions for food value chain research.

\section{Keywords}

agriculture of the middle, distribution, food hub, local food, New York agriculture, rural economic development, value chain

\section{Introduction}

The US food system has changed dramatically since the 1970s, with evidence of negative impacts for independent family farms. These are farms, henceforth referred to as "small, commercial farms," which report annual sales between US $\$ 10,000$ and US $\$ 250,000$, and with farming as the primary occupation of the owner (Hoppe, MacDonald, \& Korb, 2010). Many small, commer- 
cial farms face similar challenges marketing and distributing their products, primarily because of the difficulties in linking to food supply chains. ${ }^{1}$ In particular, accessing appropriately scaled markets is increasingly difficult for small, commercial farms as supply chains continue to become more polarized.

\section{Participation in mainstream} food supply chains is difficult for small, commercial farms. ${ }^{2}$ This is due in part to the consolidation of large-scale, supermarket retail and wholesale operations. These markets demand large volumes, low prices, and consistent quantities and qualities that meet increasingly strict safety standards. The procurement systems in such markets are often vertically and horizontally integrated, global in scale, and structured to maximize efficiency. In addition, the cost of wholesale marketing farm foods has increased considerably over the past four decades, mainly because of rising costs of labor, transportation, food packaging materials, and other inputs used in marketing (USDA, 2002).

Small, commercial farms can access direct retail markets where barriers to entry are lower (e.g., community supported agriculture, farm stands, and farmers' markets); however, where direct markets are located in proximity to farms, sales are often limited by small, remote populations and the seasonality of the markets. For example, table 1 shows that in 2009, the four farmers' markets in Madison County, NY, generated revenues of approximately US $\$ 1,000,000$ per season. However, this figure

\footnotetext{
${ }^{1}$ We follow the definition of food supply chain proposed by Clancy and Ruhf (2010b): “A network of business enterprises through which food products move from production through consumption. Typical links in the supply chain are: inputs; producer; processor; broker; distributor; wholesaler; retailer; consumer" (p. 2).

${ }^{2}$ Mainstream supply chains typically refer to a major grocery store or food service distributor, which "can supply local products...but typically do not focus on establishing meaningful links between consumers and producers" (King et al., 2010, p. 5).
}

represents sales from over 100 vendors, over half of whom sell nonfarm products. Thus, it is unlikely that a small, commercial farm could earn enough revenue simply through direct market sales if the farm is not located in close proximity to larger markets. ${ }^{3}$

Despite the difficulty of gaining access to appropriately scaled markets, there are growing opportunities for small, commercial farms. Tropp, Regland, and Barham (2008) found that "the value of directto-consumer food sales in the United States grew 37 percent between 1997 and 2002 - from US $\$ 592$ million to US\$812 million - reflecting the enormous growth in the number and accessibility of direct-to-consumer marketing outlets" (2008, p. 7). Kirschenmann, Stevenson, Buttel, Lyson, and Duffy (2008) argue that small, commercial farms are best positioned to meet the growing demand for local food because "they have the flexibility to implement innovative production and marketing systems" (p. 17).

Redeveloping appropriately scaled segments of supply chains (e.g., processors, brokers, distributors, wholesalers, and retailers) may support the viability of small, commercial farms. However, mainstream supply chains have consolidated in order to provide food to consumers as efficiently and cost-effectively as possible. Thus, it is unlikely

\footnotetext{
${ }^{3}$ For more information about the Madison County baseline economic assessment study of the farmers' markets in Madison County, New York, contact contact@madisoncountyagriculture.com
} 
that supply chains created to support small, commercial farms will be able to compete on a purely economic basis. According to Kirschenmann, Stevenson, Buttel, Lyson, and Duffy (2008), what is missing in order for small, commercial farms and mid-scale supply chains to profit from growing demand for local food is functional value chains. There are several definitions of value chains; according to Clancy and Ruhf's work on value chains in the Northeast, value chains most commonly "focus on 'adding value' to the product... [by] featur[ing] food products that are converted from raw product through processes that give the resulting product an incremental value - higher price or expanded market — in the market place... [and/or by] describ[ing] food products that obtain incremental value in the marketplace by differentiating based on product attributes such as: geographical source; environmental stewardship (production practices); food safety; or functionality" (2010a, p. 14). Participation in a value chain is thus very different from a traditional food supply chain.

In the last five years, the number of food value chains across the United States has proliferated. A May 2009 study in the Northeast was able to select 35 regional value chains for initial data collection. Many of these value chains have received ample support from governments and private foundations. Yet policy-makers lack rigorous methodologies to evaluate the contribution of local food value chains to the economic vitality and sustainability of communities and small, commercial farms. Developing these methodologies has risen to the top of many research agendas (Clancy, 2010; Committee on Twenty-First Century Systems Agriculture: National Research Council, 2010; King et al., 2010). This case study provides an account of a segment of a food value chain that was started in 2007, CNY Bounty.

\section{Background}

Central New York $(\mathrm{CNY})^{4}$ presents an interesting case through which to examine the impacts of food

\footnotetext{
${ }^{4}$ For the purposes of this paper, Central New York is defined as the region made up of the five counties of Broome, Onondaga, Oneida, Madison, and Chenango.
}

value chains, due to the large share of agriculture in the local economy, sizeable direct-to-consumer farm sales, availability of affordable land suitable for agricultural production, proximity to markets (particularly those demanding locally grown products), and predominance of small farms and small, commercial farms. Furthermore, agriculture in $\mathrm{CNY}$ is experiencing a significant shift. Dairy farming has long been the agricultural mainstay, and remains the single biggest contributor to gross agricultural sales, but the number of dairy farms has declined in recent years. Table 2 shows that between 2002 and 2007, the number of dairy farms in the five-county $\mathrm{CNY}$ region dropped from 920 to 736 ; likewise, the number of milk cows decreased from 106,600 in 1993, to 93,500 in 1999, to 77,600 in 2007 (USDA NASS, 2007). In contrast, figure 1 shows that small, commercial farms compose over a third of CNY farms. We argue that these farms are important to rural economic activity in the region. Many of these farms are diversifying their operations; for example, the number of fruit and tree nut and orchard operations increased significantly over the past decade, $106 \%$ and $18 \%$ respectively (USDA, 2009). The statistics for new farms in $\mathrm{CNY}$ are even more telling. Of the 744 farms in Madison County, 173 reported being in operation less than 10 years (USDA NASS, 2009).

Table 2. Number of Milk Cows in Central New York, 1993, 1999, and 2009, and Number of Dairy Farms in Central New York, 2002 and 2007

\begin{tabular}{|c|c|c|c|c|c|}
\hline County & $\begin{array}{c}\text { \# milk } \\
\text { cows } \\
(2009)\end{array}$ & $\begin{array}{c}\text { \# milk } \\
\text { cows } \\
(1999)\end{array}$ & $\begin{array}{c}\text { \# milk } \\
\text { cows } \\
(1993)\end{array}$ & $\begin{array}{c}\text { \# dairy } \\
\text { farms } \\
(2007)\end{array}$ & $\begin{array}{c}\text { \# dairy } \\
\text { farms } \\
\text { (2002) }\end{array}$ \\
\hline Broome & 5,700 & 6,500 & 8,600 & 44 & 61 \\
\hline Chenango & 14,000 & 21,000 & 24,000 & 194 & 247 \\
\hline Madison & 19,000 & 24,500 & 28,700 & 189 & 226 \\
\hline Oneida & 17,000 & 23,000 & 28,000 & 204 & 283 \\
\hline Onondaga & 21,900 & 18,500 & 17,300 & 105 & 103 \\
\hline tal & 77,600 & 93,500 & 106,600 & 736 & 920 \\
\hline
\end{tabular}

Sources: USDA NASS, 1999; USDA NASS, 2002; USDA NASS, 2007; USDA, 2009. 
Figure 1. Central New York Farms by Gross Sales, 2002 and 2007

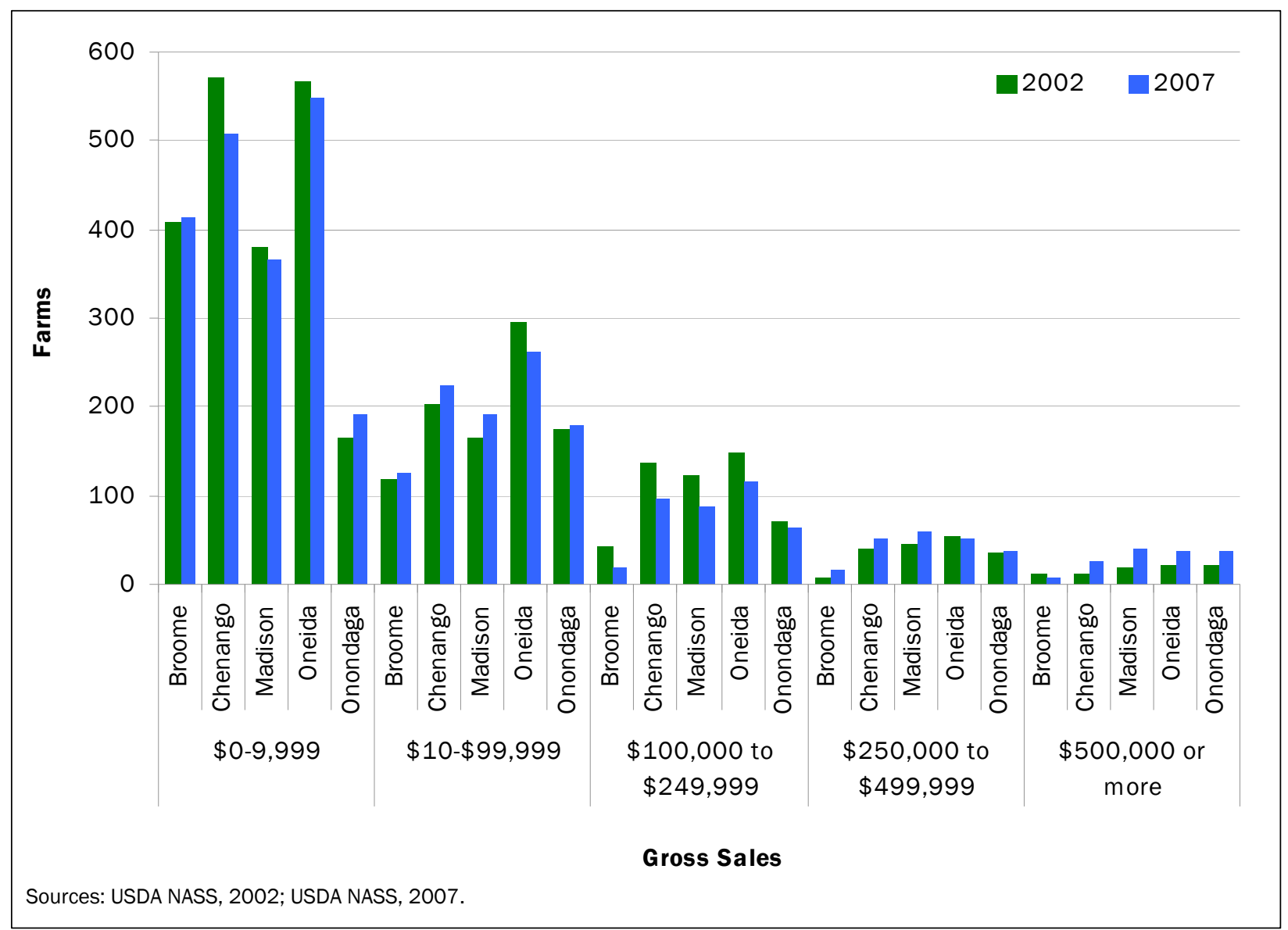

\section{CNY Bounty}

In 2007, the Chenango County Agriculture Development Council (CCADC) created CNY Bounty. ${ }^{5} \mathrm{CNY}$ Bounty is a year-round, local foods ${ }^{6}$ distribution company that is a example of a burgeoning segment of a food value chain. We argue that CNY Bounty is part of a food value chain, as

${ }^{5} \mathrm{CNY}$ Bounty was originally called Chenango Bounty. When Madison County joined the project in July 2008, the project became known as Chenango-Madison Bounty. In January 2010, the project name was officially changed to CNY Bounty as the project expanded into Onondaga County. CNY Bounty is now the legally incorporated name of the LLC.

${ }^{6}$ For the purpose of CNY Bounty, local is defined as: (1) grown and/or processed within the delivery area (currently the five-county region of Onondaga, Madison, Broome, Chenango and Oneida); or (2) grown and/or processed within New York state - used only in cases where specific products in sufficient quantity and quality are not grown within the delivery region. opposed to a standard supply chain, for several reasons. First, it provides and distributes valueadded, geographically differentiated products. Second, the process through which profits are shared involves farmers setting their own price such that they receive ample reward for their labor, regardless of their scale and/or growing practices, as opposed to products sold through the commodity market and/or mainstream supply chains. Third, CNY Bounty exhibits a high level of transparency in its business strategy, as shown by its continuous information-sharing among all participating farmers, processors, and consumers.

\section{How It Works}

Each week CNY Bounty coordinates product availability with its participating farmers and processors. CNY Bounty staff update product listings 
on its website ${ }^{7}$ according to each farmer's price, plus a 30\% mark-up to cover CNY Bounty's costs of operation, along with the total quantity available (i.e., the website can be set to reflect that farmer A has 30 butternut squash available in a given week). Currently, CNY Bounty works with 119 farmers and processors. Its customers include individual households, electronic benefits transfer (EBT) and supplemental nutrition assistance program (SNAP) recipients, restaurants, natural food stores, and educational institutions. These customers can place orders online anytime before Monday at noon for Wednesday or Thursday delivery. The website is closed on Monday between noon and 5:00 p.m. so that CNY Bounty staff can provide farmers and processors with order information. Orders placed before Monday at noon are picked up from the farm on Tuesday afternoon and delivered directly to accumulation sites (farms with ample refriger-

\section{Figure 2. CNY Bounty Drop-off Locations}

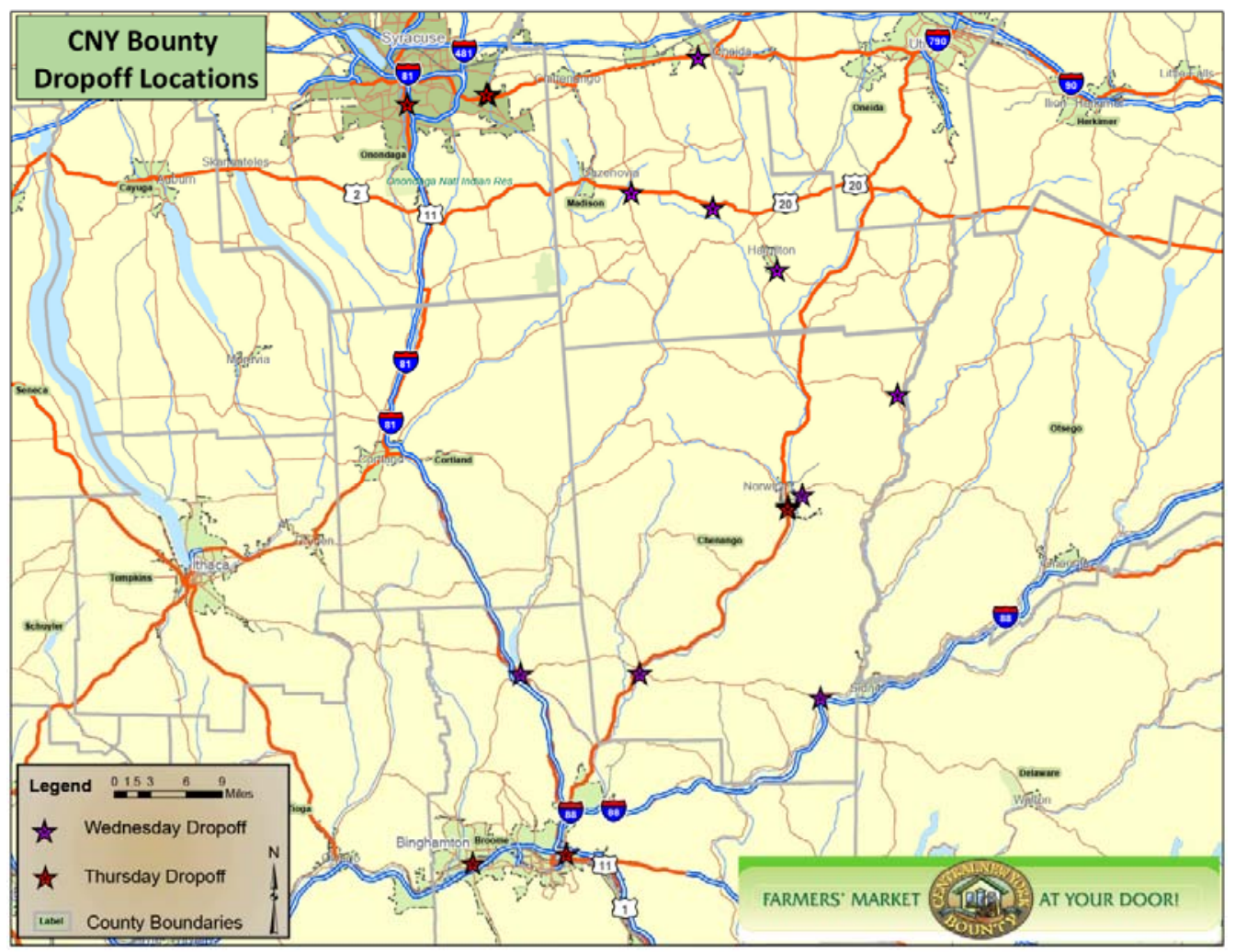

Source: CNY Bounty records 2011.

${ }^{7}$ CNY Bounty website: http://www.cnybounty.com ated space, Cornell Cooperative Extension offices, and storage and processing facilities). CNY Bounty drivers collect all products and bring them to the distribution facility, currently in Evans Farmhouse Creamery, in Greene, NY. Warehouse workers pack most of the orders on Tuesday evening, except for baked goods and other fragile or highly perishable items that need to be harvested or made, packed, and distributed on the same day. Orders placed within the delivery region for over US $\$ 35$ are delivered directly to customers' homes at no additional charge. Orders that are placed by customers who live outside the delivery area or that total less than US $\$ 35$ are delivered to one of $\mathrm{CNY}$ Bounty's 18 strategically located drop sites, shown in figure 2.

CNY Bounty works with a diverse group of farmers and processors, offering a wide assortment of

value-added fresh and processed products dairy (milk, yogurt, cheese, etc.), eggs, produce, all kinds of meats, salsas, jams, juice, maple products, honey, grains, beans, pastries, and soups, among others. In total, CNY Bounty offers customers over 1,500 items, although not all are available year-round. Participating producers employ a wide range of production methods, and vary in size from raising 20 layer hens to farming over 1,000 acres in vegetables and crops. 
Some member farmers have worked the same land for many generations, and others use CNY Bounty as a vehicle to launch their new farm and/or processing business. All participating farmers adhere to local, state, and federal regulations, sell their product above standard commodity pricing, and are not discriminated against or shown preferential treatment because of production decisions (e. g., organic, Northeast Organic Farming AssociationNOFA pledge, Certified Sustainably Grown).

\section{Organizational Structure}

Until January 1, 2011, CNY Bounty operated under the umbrella of Cornell Cooperative Extension of Chenango County and Cornell Cooperative Extension of Madison County. The transition to an independent entity was difficult due to questions about actual business ownership and to problems determining appropriate legal structure. Due to the large number of vendors with whom CNY Bounty works (particularly the large number of beginning and expanding farmers), as well as the fact that CNY Bounty delivers food to all customers regardless of socioeconomic status, CNY Bounty's executive advisory committee decided to form both a 501(c)(3) nonprofit corporation and a forprofit corporation (as a limited liability corporation (LLC). Currently, the 501(c)(3) is the sole member/owner of the LLC, although CNY Bounty is currently considering selling ownership shares in the LLC. The majority of operations take place through the LLC, but in practice, the two structures are closely aligned.

Forming a nonprofit organization has meant continued reliance on grant funding and/or public assistance for certain activities. However, if one considers the economic development assistance provided by all county and state governments to new businesses, the mold for which does not fit small, commercial agriculture, the nonprofit business structure and continued support becomes more palatable. In addition, the fact that customers paying with EBT or SNAP benefits cannot pay online for products means that delivering to these customers more than doubles CNY Bounty's labor costs when compared to other home delivery services. Given society's increasing concerns about diet-related health problems (e.g., obesity and diabetes), there may be additional rationale for continued government and private foundation support of CNY Bounty and similar programs.

\section{Sales}

As of December 15, 2010, CNY Bounty had completed over 11,000 deliveries since operations began in November 2007. These deliveries represent sales of over US $\$ 500,000$, of which over US $\$ 400,000$ was returned to member farmers and processors. The difference was retained to cover operation costs (figure 3). Table 3 presents selected indicators of CNY Bounty's performance. The average number of weekly orders increased from 26.4 to 126.5 between 2008 and 2010. Likewise, the average sales per week increased from US $\$ 1,525$ to US $\$ 5,530$ during the same period, and the average revenue returned to members increased nearly four-fold between 2008 and 2010. These figures are small, but suggest increased future sales. In August 2010, CNY Bounty began developing an institutional sales channel, which resulted in over US $\$ 2,000$ per week in average sales in the last four months of 2010.

Table 4 demonstrates that most of the 24 farms and processors selling product through $\mathrm{CNY}$ Bounty for at least three years saw increases in sales through this market outlet. Average annual sales growth rates for participating farms and processors were over $100 \%$, for 2009 and 2010 . Although we cannot provide the exact sales numbers for each of these farms (due to privacy requests from the individual producers), total sales for the 24 producers equaled $\$ 29,362.47$ (2008), $\$ 65,875.03$ (2009), and $\$ 104,194.42$ (2010). The average sales per farm were $\$ 1,223.44$ (2008), $\$ 2,744.79$ (2009), and $\$ 4,341.43$ (2010). Some producers did not experience increases in their sales due to limitations in supply and/or changes in their marketing strategies. For example, Iron Horse Farm, which experienced impressive growth in sales between 2008 and 2009 (+100\%), showed a descrease in sales through CNY Bounty in 2010 $(-11 \%)$. This was due in part to their decision to open a community supported agriculture (CSA) marketing channel in 2010, and thus to not offer as 
Figure 3. CNY Bounty Home Delivery Revenues and Orders (Excluding Wholesale), 2010

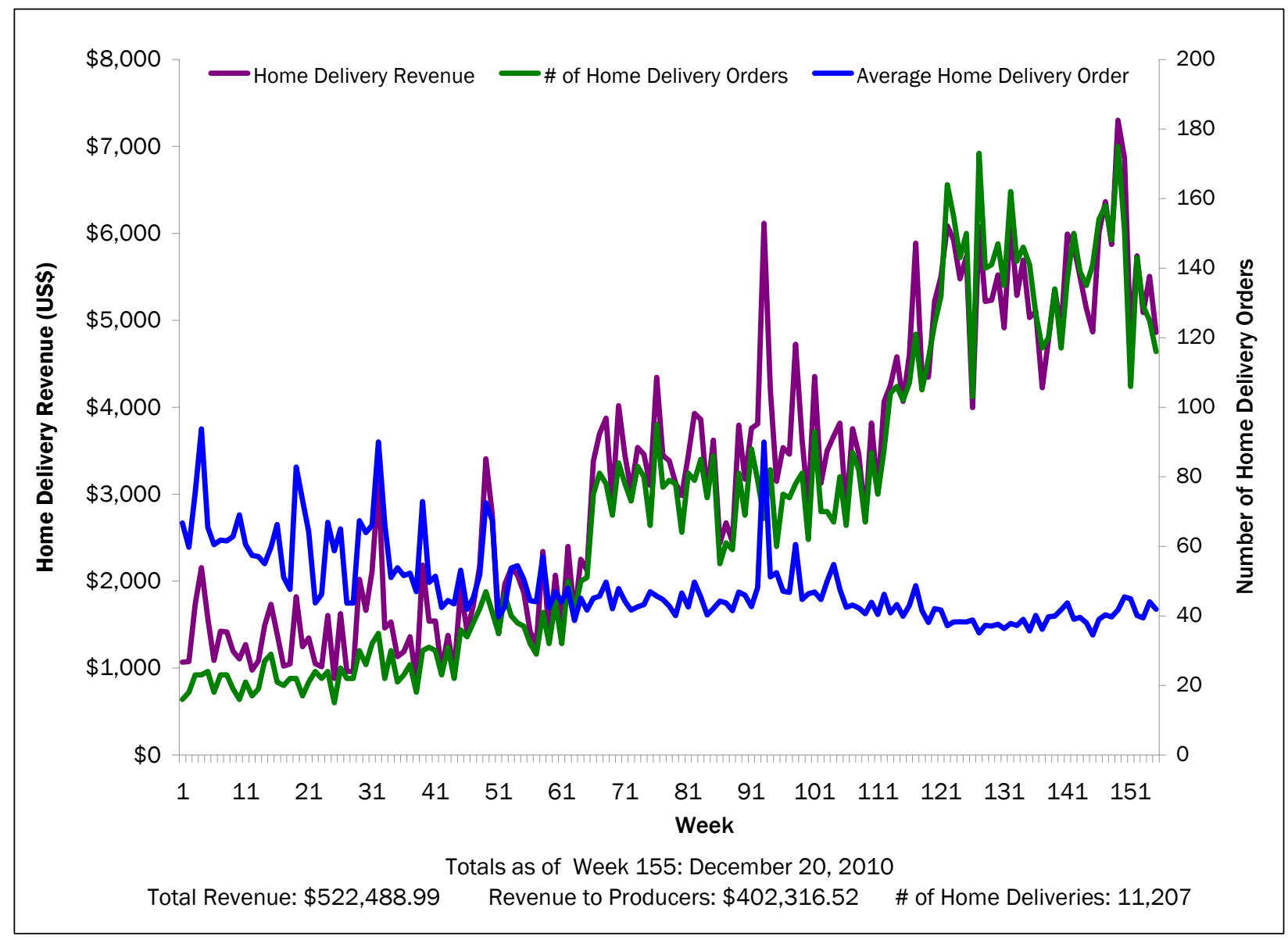

Source: CNY Bounty records 2011.

Table 3. CNY Bounty Sales, 2008-2010

\begin{tabular}{|c|c|c|c|}
\hline & 2008 & 2009 & 2010 \\
\hline $\begin{array}{l}\text { Average number of customers ordering per } \\
\text { week }\end{array}$ & 26.37 & 67.52 & 126.49 \\
\hline Average sales per week & $\$ 1,525.34$ & $\$ 3,161.26$ & $\$ 5,530.54$ \\
\hline $\begin{array}{l}\text { Number of participating farmers and } \\
\text { processors } \\
\text { (at year's end) }\end{array}$ & 58 & 89 & 119 \\
\hline Average CNY Bounty net income per week & $\$ 350.83$ & $\$ 727.09$ & $\$ 1,272.03$ \\
\hline $\begin{array}{l}\text { Average revenue returned to participating } \\
\text { farmers and processors per week }\end{array}$ & $\$ 1,174.51$ & $\$ 2,434.17$ & $\$ 4,258.52$ \\
\hline $\begin{array}{l}\text { Average total dollar amount per home } \\
\text { customer ordera (US\$) }\end{array}$ & $\$ 58.44$ & $\$ 46.80$ & $\$ 40.37$ \\
\hline
\end{tabular}

Source: CNY Bounty records 2011.

a The minimum order for home delivery was changed from US $\$ 50.00$ to US $\$ 35.00$ in mid-year 2008 . many products through CNY Bounty.

\section{Benefits: Increased \\ Market Access}

CNY Bounty provides a new distribution channel for farmers and processors. Having information about CNY Bounty members but not about nonmembers makes it difficult to assess CNY Bounty's impacts fully. However, for new farmers and processors 
CNY Bounty facilitates market access, particularly given the high barriers to market entry due to existing supply chain structures. It is possible to identify two groups that have experienced a clear net benefit from sales through CNY Bounty: Amish farmers, and beginning farmers and processors.

In the last five years, dozens of Amish families ${ }^{8}$ have moved to $\mathrm{CNY}$ and are reclaiming abandoned or underutilized farmland, including unsuccessful dairy farms. Many of these Amish farmers produce very high quality directmarketable agricultural products. However, beyond regional farmers' markets and a few Amish stores that have opened recently, they lack market access. The majority of the Amish farmers within the region do not drive motorized vehicles, and thus experience difficulty distributing their products.

From a distributor's perspective, there are added challenges working with Amish farmers. Particularly when dealing with fresh produce, product availability can change very quickly. The CNY Bounty website needs to be upto-date at all times. If customers do not receive their entire order, they can become frustrated, an experience which can reflect poorly on all of the participating farmers and processors. Stevenson and Pirog (2008) emphasize that local food distribution systems must combine product reliability and high-quality production in order to establish trust with consumers and generate re-purchase behaviors. It takes $\mathrm{CNY}$ Bounty staff additional time to communicate with Amish farmers, as they generally do not use computers or fax machines and many do not have telephones. Product listings are mailed to or dropped off with Amish farmers so that they can

8 This number is an estimate based on the authors' experience living in the community.
Table 4. CNY Bounty Farms That Have Been Consistently Selling Product Through CNY Bounty for at Least 3 Years, by Percent Change in Sales, 2008-09 and 2009-10

\begin{tabular}{lcc}
\hline & $\begin{array}{c}\text { \% Change } \\
\text { '08-'09 }\end{array}$ & $\begin{array}{c}\% \text { Change } \\
\text { '09-'10 }\end{array}$ \\
\hline Amazing Grains & $65 \%$ & $39 \%$ \\
Baker's Maple Products & $-80 \%$ & $100 \%+$ \\
Chenango Coffee Roasters & $100 \%+$ & $90 \%$ \\
Drover Hill Farm & $79 \%$ & $100 \%+$ \\
Evans Farmhouse Creamery & $54 \%$ & $75 \%$ \\
Finger Lakes Farmstead Cheese Co. LLC & $-11 \%$ & $100 \%+$ \\
Foothill Farms & $58 \%$ & $100 \%+$ \\
G\&M Farms & $-12 \%$ & $51 \%$ \\
Ingallside Meadows Farm & $100 \%+$ & $100 \%+$ \\
Iron Hoof Farm & $100 \%+$ & $-11 \%$ \\
Jewett's Cheese House & $100 \%+$ & $100 \%+$ \\
Kutik's Honey Farm LLC & $-39 \%$ & $100 \%+$ \\
La Maison Blanche Bakery & $56 \%$ & $47 \%$ \\
Lamb's Quarters Organic Farm Store & $-13 \%$ & $50 \%$ \\
Meadowood Farms & $100 \%+$ & $83 \%$ \\
Mosher Farms & $100 \%+$ & $33 \%$ \\
Organically Hip LLC & $100 \%+$ & $-7 \%$ \\
Painted Goat Farm & $100 \%+$ & $-67 \%$ \\
Poolville Country Store & $100 \%+$ & $9 \%$ \\
Purdy \& Sons' Foods, Inc. & $100 \%+$ & $-67 \%$ \\
Quarry Brook Farms & $42 \%$ & $23 \%$ \\
Taylor, Lash & $100 \%+$ & $100 \%+$ \\
Upstate Harvest & $90 \%$ & $99 \%$ \\
\hline Average per farm & $100 \%+$ & $90 \%$ \\
\hline
\end{tabular}

Source: CNY Bounty records 2011. check and confirm product availability. Establishing these communication channels may not always be cost effective, but it provides an important resource for the growing numbers of Amish farmers in CNY.

We argue that new farm businesses are important to the rural economy in CNY because they represent a large and growing proportion of overall farms. For instance, the USDA National Agricultural Statistics Service (2007) finds that 173 of the 
744 farms in Madison County, NY, have been in existence for less than 10 years. Many of these new farms are small (under US $\$ 10,000$ in sales), which tends to boost total farm numbers, but they do not fill the void resulting from failing dairy farm and aging farmers. Gillespie, Hilchey, Hinrichs, and Feenstra (2007) state that one role of farmers' markets in rebuilding localized food systems is "incubating small businesses that then may expand beyond farmers' markets" (p. 75). In this capacity, CNY Bounty staff assist farmers and processors in identifying market opportunities, improving business skills (e.g., writing invoices and packaging), and providing market information. The staff mostly do this through weekly interactions with farmers, when they provide consistent feedback from consumers, the CNY Bounty bookkeeper, and CNY Bounty drivers on a range of issues, including invoices, packaging, and marketing opportunities. Consequently, CNY Bounty began developing an institutional wholesale market channel in fall 2010. Though this aspect of the business is new and sales are relatively low (averaging about US $\$ 2,000$ per week during the 2010 fall semester), the net benefits of such a market to participating farmers and processors are more straightforward. Without the product aggregation infrastructure and the marketing connections that CNY Bounty facilitates, participants would not be able to participate in this channel.

\section{Challenges: Small/Beginning Farms and Low-Income Customers}

CNY Bounty is still not economically sustainable. Grant funding is required in order to employ a marketing manager and a project coordinator. A significant reason outside resources are still required is the large number of small farmers and processors with whom CNY Bounty works, making operations more complex and labor-intensive than segments of more established supply chains and food value chains. Working with Amish producers and beginning farmers and processors takes a substantial amount of staff time. In order to accommodate these new and expanding businesses, while still maintaining high standards of quality, CNY Bounty hired a quality control manager for 20 hours per week in March 2010. The CNY
Bounty executive advisory committee decided that this was a good investment, despite the fact that it contributed to continued reliance on grant funds.

From the project's inception, the advisory committee has committed to delivering products to homebound individuals as well as to EBT and SNAP recipients. The number of SNAP recipients receiving home delivery continues to grow. However, working with SNAP recipients is labor intensive. CNY Bounty's EBT machine, acquired through a grant from NYS to Cornell Cooperative Extension of Madison County (which processes EBT/SNAP benefits), is based on its connection with a traditional farmers' market. As CNY Bounty does not administer a traditional farmers' market, all payment must go through Cornell Cooperative Extension of Madison County. When a customer wants to pay using their EBT/SNAP funds, a driver must make sure the customer will be home when the delivery is made, have the customer sign a form, and phone in the order in order to put a hold on the account for the amount required. After the driver finishes his or her delivery route, the transaction must be processed on the physical EBT machine housed at the CCE office. The money from SNAP payments is then placed in CCE Madison County's account, and CNY Bounty invoices them to receive payment. As a result, CNY Bounty's labor expenses more than double on these deliveries.

Because CNY Bounty has never been appropriately capitalized, cash flow continues to be a constant struggle. While grant funding has its benefits, a major drawback is that funds are often slow to arrive, which may lead to less-than-optimal business decisions. When CNY Bounty started, Chenango County purchased a ready-made web storefront. In late 2009, with funding from the NY Farm Viability Institute, CNY Bounty transitioned to a new website built by a professor at a local college. The professor and his students certainly had the best of intentions, but the website has been inadequate, especially as Bounty sales doubled in a six-month period. The result has been continued crashes, lost sales, and reliance on a volunteer retired web specialist through countless nights and 
weekends. Perhaps most significantly, CNY Bounty has not implemented a credit card payment system on the site due to its tenuous operation.

This has exacerbated cash flow issues as customers are often slow to send in checks, and it requires additional staff capacity and resources to follow up with customers who have not paid. For a webbased business, the impacts of an inadequate website are severe.

\section{Recommendations and Suggestions} for Further Research

CNY Bounty provides an interesting case study of a segment of a food value chain: an attempt to scale up the capacity of small, commercial farms and to provide product of consistent quantity and quality for a local market. There is growing evidence that CNY Bounty offers farmers and processors the possibility of reducing marketing and distribution costs. Figure 4 uses Drover Hill Farm, a CNY Bounty participating farm, as an example to show that the number of hours spent in marketing and distribution through CNY Bounty is just a fraction of the hours the farm spends in marketing and distributing through farmers' market and direct sales. Even though CNY Bounty represents only $8 \%$ of the farm's total sales, there is a potential margin for an increase in its participation since the

Figure 4. Drover Hill Farm as an Example of Hours Spent in Marketing and Distribution Activities Compared with Percent of Sales and Percent of Final Price Received for Each

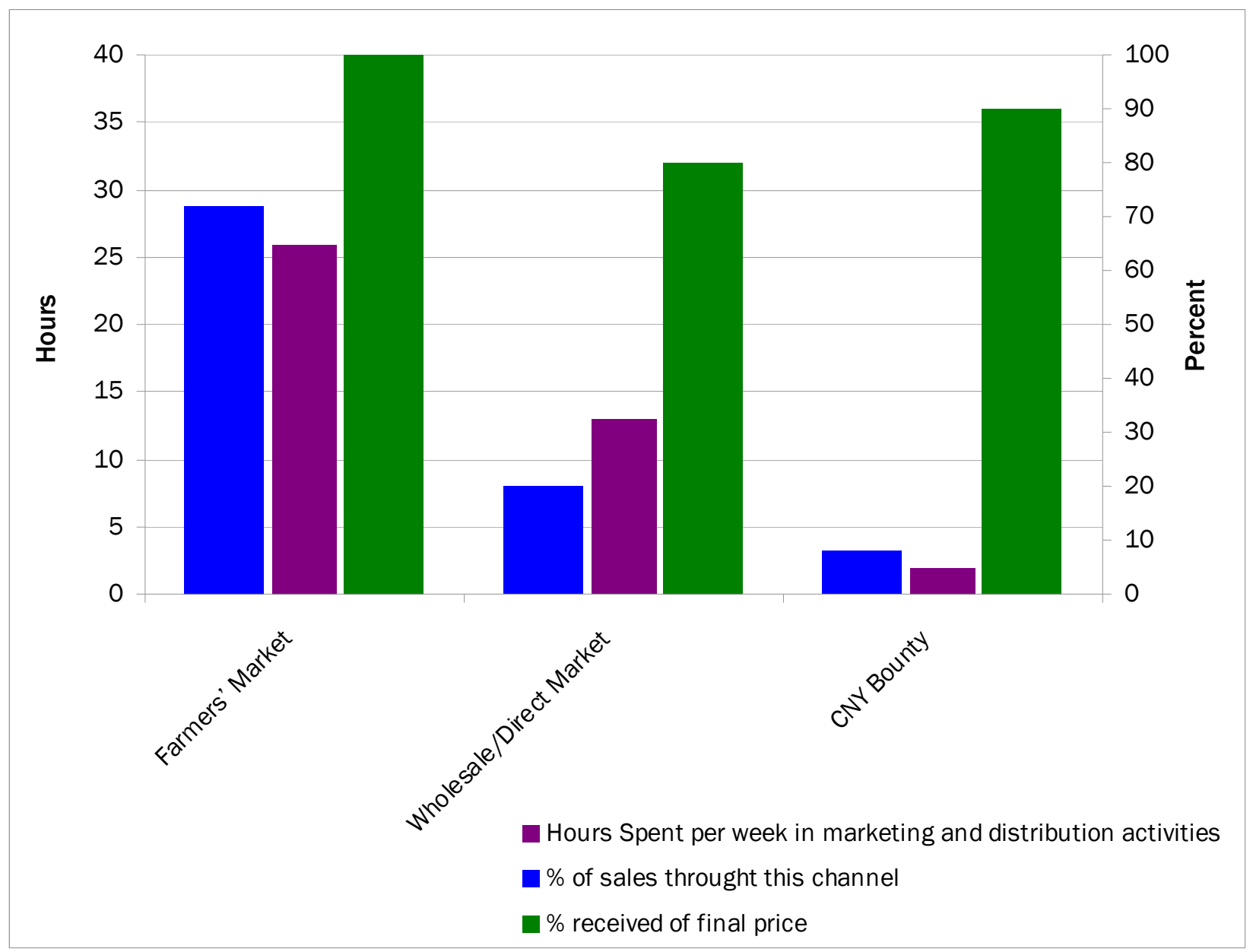

Source: Jablonski, B.B.R. (2009). Interview with William and Stephanie Lipsey, January 11, 2011. Note: Wholesale/direct market includes restaurants and grocery stores where product is marketed and distributed directly by farmers and processors. 
percent of final price received by the farmer is somewhat higher than through wholesale/direct markets. In order to effectively evaluate CNY Bounty, this kind of information needs to be gathered and analyzed for a larger number of participating farms.

A full project evaluation would require the development of congruent measures of the planning and implementation processes for all participants - in this case, the 119 farmers and processors who have sold product through CNY Bounty. Since CNY Bounty is an ongoing operation, we would need to distinguish between the formative and summative parts of the evaluation process. Most of the information in the present paper represents the evolution of CNY Bounty in terms of initial and ongoing activities, rather than an assessment of its impact. Nevertheless, CNY Bounty's institutional sales channel offers the opportunity to evaluate a specific aspect of the program. One natural product of this research would be to evaluate the performance of this program's first year of existence.

Further research would require a comprehensive survey of all the participating farmers and processors in CNY Bounty. The main goal of this evaluation stage would be to collect data on a wide range of topics, including sales, preference for selling through CNY Bounty, and more detailed information about the costs and benefits of being part of the program. This information would allow us to assess the impact of CNY Bounty on its participants and on the region's economic development.

The descriptive information is useful for obtaining a general idea of the project and its immediate impact. However, we need to develop more case studies such as the Drover Hill case that elicit participants' perceptions regarding benefits derived from participation in CNY Bounty — particularly vis-à-vis their other marketing channels. What thoughts do stakeholders knowledgeable about the program have concerning program operations, processes, and outcomes? What are participants' and stakeholders' expectations? What features of the project are most salient to the participants? What changes do participants perceive in their behavior as a result of their involvement in the project? Exploring these issues systematically would provide a richer picture of the economic and social impact of CNY Bounty and shed light on further steps in the study of this and other local food value chains.

\section{Concluding Remarks}

The growing consumer demand for local foods has prompted substantial innovations in food value chains. Such innovations pose new market participation challenges and opportunities for small, commercial farms in the United States. In this case study, we examine these issues for CNY Bounty, a segment of a food value chain that gives farmers and processors the opportunity to benefit from participation in local value chains as an alternative to direct market channels such as farmers' markets and community supported agriculture (CSA) arrangements. Our analysis suggests that $\mathrm{CNY}$ Bounty is an attractive option among distribution channels for participating farmers. This case study also underscores the importance of an intermediary in facilitating market coordination and valuesharing among chain members. However, the case also highlights the economic sustainability challenges that CNY Bounty faces today. Future research should focus on the identification of appropriate policy interventions necessary to facilitate the emergence of value chains similar to CNY Bounty, and on conducting systematic studies using counterfactual outcomes in order to fully assess the economic, social, and environmental benefits of supporting them.

\section{Acknowledgments}

The authors wish to thank the David R. Atkinson Center for a Sustainable Future, the Cornell Small Farm Program, and Cornell Cooperative Extension for their support of continued work on this project as well as of future food value chain research throughout New York state.

\section{References}

Birthal, P. S., \& Joshi, P. K. (2007). Institutional innovations for improving smallholder participation in high-value agriculture: A case of fruit and vegetable growers' associations in India. Quarterly Journal of International Agriculture, 46(1), 49-67. 
Blanchard, T. C., \& Matthews, T. L. (2008). Retail concentration, food deserts, and fooddisadvantaged communities in rural America. In C. C. Hinrichs \& T. A. Lyson (Eds.), Remaking the North American food system: Strategies for sustainability (pp. 201-215). Lincoln, NE: University of Nebraska Press.

Cairns, S. (2005). Delivering supermarket shopping: More or less traffic? Transport Reviews, 25(1), 51-84. http://dx.doi.org/10.1080/0144164042000218391

Clancy, K. (2010). A priority research agenda for agriculture of the middle. Retrieved from http://www.agofthemiddle.org/

Clancy, K., \& Ruhf, K. (2010a). Regional value chains in the Northeast: Findings from a survey. The Northeast Regional Lead Team Project. http://www.nefood.org/page/publications-1

Clancy, K., \& Ruhf, K. (2010b). Regional value chains project description. The Northeast Regional Lead Team Project. Retrieved from http://www.nefood.org/page/publications-1

Coley, D., Howard, M., \& Winter, M. (2009). Local food, food miles and carbon emissions: A comparison of farm shop and mass distribution approaches. Food Policy, 34(2), 150-155. http://dx.doi.org/10.1016/j.foodpol.2008.11.001

Committee on Twenty-First Century Systems Agriculture: National Research Council. (2010). Toward sustainable agricultural sysyems in the $21^{\text {st }}$ century. Washington, DC: National Academies Press.

Gillespie, G., Hilchey, D. L., Hinrichs, C. C., \& Feenstra, G. (2007). Farmers' markets as keystones in rebuilding local and regional food systems. In C. C. Hinrichs, \& T. A. Lyson (Eds.), Remaking the North American food system: Strategies for sustainability (pp. 65-83). Lincoln, NE: University of Nebraska Press.

Gorton, M., Dumitrashko, M., \& White, J. (2006). Overcoming supply chain failure in the agri-food sector: A case study from Moldova. Food Policy, 31(1), 90-103. http://dx.doi.org/10.1016/ j.foodpol.2005.08.003

Hellin, J., Lundy, M., \& Meijer, M. (2009). Farmer organization, collective action and market access in Meso-America. Food Policy, 34(1), 16-22. http://dx.doi.org/10.1016/j.foodpol.2008.10.003

Heffernan, W. (1999). Consolidation in the food and agriculture system. Report to the National Farmers
Union. Retrieved from http://home.hiwaay.net/ becraft/NFUFarmCrisis.htm

Hendrickson, M., Heffernan, W., Howard, P., \& Heffernan, J. (2001). Consolidation in food retailing and dairy: Implications for farmers and consumers in a global food system. (Report to the National Farmers Union.) Retrieved from http://www.foodcircles.missouri. edu/whstudy2.pdf

Hoppe, R. A., MacDonald, J. M., \& Korb, P. (2010). Small farms in the United States: Persistence under pressure (Research bulletin EIR-63). Washington, DC: U.S. Department of Agriculture: Economic Research Service. Retrieved from http://ageconsearch.umn. edu/bitstream/58300/2/EIB63.pdf

Jablonski, B. B. R. (2011). Interview with William \& Stephanie Lipsey. Unpublished raw data.

James, P., \& Hopkinson, P. (2001). Virtual traffic: E-commerce, transport and distribution. In J. Wilsdon, (Ed.), Digital futures: Living in a dot.com world (pp. 165-199). London, UK: Earthscan.

Kirschenmann, F., Stevenson, G. W., Buttel, F., Lyson, T. A., \& Duffy, M. (2008). Why worry about the agriculture of the middle? In T. A. Lyson, G. W. Stevenson, \& R. Welsh, (Eds.), Food and the MidLevel Farm (pp. 3-22). Cambridge, MA: The MIT Press.

King, R. P., Hand, M. S., DiGiacomo, G., Clancy, K., Gómez, M. I., Hardesty, S. D., \& McLaughlin, E. W. (2010). Comparing the structure, size, and performance of local and mainstream food supply chains (Research bulletin ERR-99). Washington, DC: U.S. Department of Agriculture, Economic Research Service. Retrieved from http://ucbiotech.org/ issues pgl/ARTICLES/ERS $\% 20$ report $\% 20$ Compa ring $\% 20$ the $\% 20$ Structure, $\% 20$ Size, $\% 20$ and $\% 20$ Perf ormance $\% 20$ of $\% 20$ Local $\% 20$ and $\% 20$ Mainstream \%20Food \%20Supply\%20Chains/ERR99.pdf

LaLonde, B. J., \& Pohlen, T. L. (1996). Issues in supply chain costing. International Journal of Logistics Management, 7(1), 1-12. http://dx.doi.org/ $\underline{10.1108 / 09574099610805395}$

Lane, S. D., Keefe, R. H., Rubinstein, R., Levandowski, B. A., Webster, N., Cibula, D. A., \& Brill, J. (2008). Structural violence, urban retail food markets, and low birth weight. Health \& Place, 14(3), 415-423. http://dx.doi.org/10.1016/j.healthplace.2007. $\underline{08.008}$ 
Packaged Facts. (2011). The future of food retailing in the U.S. (3rd ed.). Aarkstore Enterprise. Retrieved from http://www.aarkstore.com/reports/The-Future-ofFood-Retailing-in-the-U-S-3rd-Edition-92266.html

Rich, K. M., Ross, R. B., Baker, A. D., \& Negassa, A. (2010). Quantifying value chain analysis in the context of livestock systems in developing countries. Food Policy, 36(2), 214-222. http://dx.doi.org/10.1016/j.foodpol.2010.11.018

Schmit, T. M. \& Gómez, M. I. (2010). Developing viable farmers markets in rural communities: An investigation of vendor performance using objective and subjective valuations. Food Policy, 36(2), 119-127. http://dx.doi.org/10.1016/ j.foodpol.2010.10.001

Stephenson, G., Lev, L., \& Brewer, L. J. (2008). “I'm getting desperate": What we know about farmers' markets that fail. Renewable Agriculture and Food Systems 23(3), 188-199. http://dx.doi.org/ $\underline{10.1017 / \mathrm{S} 1742170507002153}$

Stevenson, G. W., \& Pirog, R. (2008). Values-based supply chains: Strategies for agrifood enterprises of the middle. In T. Lyson, G. W. Stevenson, \& R. Welsh (Eds.), Food and the mid-level farm: Renewing an agriculture of the middle (Part III, chapter 7). Cambridge, MA: MIT Press.

Tropp, D., Regland, E., \& Barham, J. (2008). The dynamics of change in the U.S. food marketing environment (Agriculture Handbook 728-3). U.S. Department of Agriculture: Agricultural Marketing Service and Marketing Services Program. Retrieved from http://ddr.nal.usda.gov/bitstream/10113/46041/ 1/CAT31029606.pdf

USDA. (2002). Profiling consumption in America. U.S. Department of Agriculture: Agricultural Fact Book, 2001-2002. http://www.usda.gov/factbook/ chapter2.htm
USDA National Agriculture Statistical Service (NASS). (1999). New York County Estimates 1992 - 1999. U.S. Department of Agriculture National Agricultural Statistics Service. Retrieved from http://www.nass. usda.gov/Statistics_by_State/New_York/Publicati ons/County_Estimates/1999/99-milk.pdf

USDA National Agriculture Statistical Service (NASS). (2002). 2002 Census publications: State and county profiles, New York. U.S. Department of Agriculture National Agricultural Statistics Service. 2002 Census of Agriculture. Retrieved from http://www.agcensus.usda.gov/Publications/ 2002/County Profiles/New York/index.asp

USDA NASS. (2007). 2007 Census publications: State and county profiles, New York. U.S. Department of Agriculture: National Agricultural Statistics Service. 2007 Census of Agriculture. Retrieved from http://www.agcensus.usda.gov/Publications/ 2007/Online Highlights/County Profiles/ New York/index.asp

USDA NASS (2009). Farm statistics. U.S. Department of Agriculture National Agricultural Statistics Service. Retrieved from http://www.nass.usda.gov/ Publications/Ag Statistics/2009/2009.pdf

USDA ERS. (2010). Food environment atlas. U.S. Department of Agriculture Economic Research Service. Retrieved from http://maps.ers.usda.gov/ FoodAtlas/

Vermeulen, S., Woodhill, J., Proctor, F., \& Delnoye, R. (2008). Chain-wide learning for inclusive agrifood market development: A guide to multi-stakeholder processes for linking small-scale producers to modern markets. London, UK: International Institute for Environment and Development. Retrieved from http://www.regoverningmarkets.org/en/ resources/global/chain_wide_learning_guide_ for inclusive agrifood market development 